\title{
Looking West, not South: The Anglo-American Films Agreement and the North on film, 1948 to 1958.
}

Alan Hughes, University of Central Lancashire.

The North of England is most potently and, arguably, most recognisably defined in conceptual rather than spatial terms. Whilst notions of its physical environment frame the North as either a harsh industrial or an equally unforgiving and severe rural, it exists as a geographically ambiguous entity - certainly at its boundaries - occupying instead an imagined location where the (real and perceived) socio-cultural values, attitudes, and traditions of its inhabitants serve to define it as an entity populated by a particular breed of, ostensibly working class, individuals (Dellheim 1986: 217; Pocock 1978: 16-27; Shields 1991: 229-231).

What is perhaps surprising about such a conceptualisation is how the most resonant expressions of Northern identity and Northern-ness are mediated through the prism of an equally geographically ill-defined South of England, which is ascribed with a set of traits and characteristics that are oppositional in nature to those employed in defining the North. Thus the North is [internally] conceptualised as independent-minded, straight-talking, practical, friendly, and meritocratic. In contrast the South is positioned as subservient, evasive, wasteful, unfriendly, and nepotistic (Russell 2004: 37). Equally, this assertion of Northern 'otherness' holds true for external [Southern] views of the North where the aforementioned internally perceived Northern qualities of independence, straight-talking, practicality, friendliness, and meritocracy, are reworked in the South to define the North as, truculent, insensitive/rude, unsophisticated, intrusive, and parochial (Russell, 2004: ibid). Irrespective of whether or not these dichotomies capture a material reality or exist only as contrasting regional mythologies, since the mid-nineteenth century definitions of the North and what constitutes Northern-ness have been calibrated - and celebrated - in terms of not being [like] the South.

These competing visions of North and South are not however the respective products of two equal entities arriving at different conclusions. Instead the reasons for this difference can be best understood as reflecting the dynamics of the hegemonic relationship between a 'core' South and a 'peripheral' North and the imbalances in economic, political, and sociocultural power that such a relationship entails (Russell 2004: 8-9). In historical terms much has been noted on the primacy of the South over the North; ranging from Jewell's observation that by the eleventh century the ruling elites of the South had secured military and political domain over the North, to Scott's detailing of the economic triumph of the South from the early twentieth century onwards (Jewell 1994: 22-24; Scott 2007: passim). In addition to these tangible realities of power and control Weiner identified that, by the turn of the twentieth century, the 'Southern metaphor' for framing English identity had won 
out and the cultural hegemony ultimately positioned the North as an 'other' to the conceptualisations of what constituted authentic England and Englishness (Weiner 1981: 42). As such, throughout the twentieth century the semantics and semiology employed in defining England and 'Englishness' have been those typified by imagery ascribed to a bucolic 'rural idyll' that are synonymous with conceptualisations of the South of England, that also includes a dynamic and sophisticated (deindustrialised) London, whose status as the metropolis is highlighted through the emphasis of historical, cultural, and political capital. Inevitably, given the dominance of London in the funding, location, and creative and industrial control over the culture industries - notably the British film industry (Scott 2007: $126)$ - the North on film throughout the twentieth century was consistently portrayed as a working class environment - either a tough industrial or similarly demanding rural - and was therefore positioned as an 'other' to the portrayals of authentic England and Englishness. Accordingly, and whilst the representations of the North on film largely adhered to positive readings of the Northern working class as stoical, meritocratic, egalitarian, and hard-working (Richards 1997: 252-279), the North remained bound by wider terms of reference that positioned the North as not only different but inferior to a set of established norms that cemented the primacy and superiority of the South.

Despite having a cinematic presence dating back to the earliest days of film exhibition (Toumlin 2006: 1-56) it was not until the late 1950s that the North of England had its moment and the North on screen became, briefly and with a small cycle of films, the darling of the British film industry. Beginning with January 1959s release of Room At The Top (1959) and ending with Billy Liar (1963) the phenomenon known variously as the 'British new wave', 'Northern [social] realist movement', or 'kitchen sink drama' was composed of a body of films where the main protagonists were working class individuals experiencing the (real and imagined) challenges of contemporary working class life. The representations of the North within this canon of work were not, however, simply a retreat into pre-war (and earlier) maxims of the North as a working class environment, although long established tropes pertaining to class, temperament and environment were still discernible. Instead the North was the location where the plot subject matter addressed previously taboo themes; unwanted or unplanned pregnancy, Room at the Top (1959), A Kind of Loving (1962), and A Taste Of Honey (1961); infidelity, Saturday Night and Sunday Morning (1961), and again Room At The Top; and most significantly a sense of disaffection - ranging from ennui to outright hostility - with the postwar society, Loneliness of the Long Distance Runner (1962), This Sporting Life (1963), Billy Liar (1963), and, again, both Saturday Night and Sunday Morning and A Kind of Loving.

The existing literature has provided excellent commentary upon the substance and impact of these and other films that fall within, or very close to, the British new wave. Each of Hell Is A City (1960), No Love for Johnnie (1961), The Angry Silence (1961), and Payroll (1961) are all set/partly set in the North and include grittier and more iconoclastic portrayals of working class life than had previously been the case in British film. However the genesis of 
this cycle of films has been subject to much less scrutiny and Lindsay Anderson's J'accuse of 1957 is often assumed as indicating how the cosy representations of class during the decade following the end of the war were out of kilter with both the creative direction of the culture industries and wider British society and, implicitly, that the arrival of the British 'new wave' was a reaction to this dissonance:

What sort of cinema have we got in Britain? First of all it is necessary to point out that it is an English cinema (and Southern English at that), metropolitan in attitude, and entirely middle-class. (Anderson 1957: 157)

It is evident that by the late 1950s the overall stylistic and thematic tone of British film outputs did not accurately reflect either the mood of cinema audiences or wider society. Yet it is far too simplistic to attribute the emergence of the British new wave and the resultant shifts within British film outputs as a phenomena arising out of resistance to both/either the dominant discourse(s) of British film and/or the influences of the 'postwar settlement' evident across British social, political, and economic life, whereby conceptualisations of national character were broadened to incorporate - or at least accommodate - working class identities. On this point, although the role of American capital has been explored with reference to British film as an industrial process in the 1948-58 period (Street 1997: 14-17; Murphy 1992: 256-275), remarkably little consideration has been given to the impact of American finance and implicitly American domestic audiences in influencing British film outputs as a cultural product during the same time. Equally, when addressing the emergence of the British 'new wave' of the late 1950s, the influence of American cinematic forms - and American finance for British film - in the decade beforehand is particularly neglected.

An examination of Northern-set films made between 1948 and 1958 indicates that the impact of America on the representations of the North were profound. Rather than gazing either enviously or contemptuously Southward, the North's embrace of American cinematic influences turned its focus outward or, more accurately, Westward. Equally the British new wave films emerging at the end of the 1950s that are widely associated with the North owed much more to this earlier body of American-influenced work than has previously been recognised. American cinematic forms in general and, specifically, the body of work from 1948 to 1958 involving American actors in Northern-set films were instrumental in the emergence of the British 'new wave'. The Anglo-American Films Agreement of 1948 not only served as a source of capital for the British film industry but influenced contemporary and future stylistic and thematic forms in British film, particularly with reference to the North of England.

America and the British film industry 1948-1958.

The height of American funding for the British film industry occurred in the 1960s, peaking in 1967 with American studios providing 90 per cent of production finance for British film 
outputs of that year (Murphy 1992: 258) (equating with $f 22.8$ million (Perilli 1983: 378)). This level of investment was borne out of a number of structural factors; anti-trust legislation compelling American studios to relinquish their cinemas, thereby increasing the importance of overseas revenue streams; the subsidy available under the Eady Levy for film production in Britain; and the competitively priced and readily available studios and studio personnel in Britain (Street 1997: 20). There was also a clear cultural imperative in place insofar as the stateside popularity of British popular culture in the 1960s - ranging from James Bond to the Beatles to Carnaby Street - embodied Britain and things British with a previously unheralded degree of cachet in the eyes of the American consumer (Marwick 2011: 412-482; Murphy 1992: 257). However prior to this, given the parlous financial and physical state of the film industry in the immediate postwar years, American capital had played an equally if not more important role in the funding of British film.

In August 1947, facing a desperate need for foreign capital - especially US dollars - to fund the purchase of essential overseas goods, the UK treasury imposed a 75 per cent duty on American film imports. Confounding the assumptions of the British government that the Americans would, begrudgingly, pay this duty the Motion Picture Association of America (MPAA) orchestrated a highly effective boycott and the supply of American films for exhibition in Britain dried up (Colman 2009: 413; Burnup 1948: 19). This situation provided a short-term boost to British film production as studios hastened as best they could to fill the gaps arising from the absence of American films for exhibition. Yet by early 1948, given that the British film industry had still not recovered from wartime privations, it was clear that British production would not be able to meet the demands of either exhibitors or audiences. In March 1948, despite well-founded British misgivings and under terms that were far from generous to Britain, the Anglo-American Films Agreement was signed (HC Deb (1948) 452 col. 737-778). The key provisions of this agreement were that, for each of the two years commencing $14^{\text {th }}$ June 1948 (after which amounts would be subject to renegotiation), American film studios could remit up to $\$ 17$ million US in revenue that had been paid by Britain for imported American films. Balances above this were 'blocked' from repatriation to the USA although they could be used for investment in film production in Britain as well as the acquisition of [British] film rights, prints and advertising and, significantly, the purchase of capital assets such as studios, patents, and technology (although not cinemas). Additional sums equivalent to those remitted to Britain from America, in respect of payments for British films exhibited in the USA, could be removed from Britain (HC Deb (1948) $450 \mathrm{col} .862-864$ ).

The legacy of this agreement was that the immediate crisis in British film exhibition was averted as American films began to arrive in Britain again. In the longer term, substantiating the concerns of those opposed to the agreement that British capital assets would be acquired by the Americans and paid for with 'blocked' money originating from British cinemagoers (HC Deb (1948) 452 col. 740-742), American studios invested heavily in British film production - a pattern of investment that was to persist until the oil shock of 1973-74 
when American capital retreated from UK film production (Perilli 1983: 378; Romer 1993: $46,52-55)$. This investment resulted in large numbers of 'runaway productions'. These were American financed British made films - thereby satisfying the statutory requirements to be counted as British films for exhibition quota purposes - that were intended to appeal to American consumers (often through plots and settings that emphasised tropes of English identity familiar to American audiences) as well as the British market (Stubbs 2009: 1; Murphy 1992: 257). Estimates of the numbers of these runaway films identify that, between 1950 and 1959, "about 170" films were produced in Britain by American film studios (Harper and Porter 2003: 14), whilst between 1950 and 1957 there were "over 100 films" in the same category (Street: 1997: 20). This amounts to c. 15 per cent of British film outputs during those periods. However the changing landscape of British film production in the 1948-58 period is not reflected by these figures which underestimate by half the extent of American influence in British film outputs.

Of the 1171 (long fiction) films made in Britain between 1948 and 1958 some 348 (30 per cent) were 'Americanised', meaning that these films had either an American/Hollywood star or co-star and/or a narrative that made an explicit reference to America/Americans that was integral to the progression of the plot. Relating to whether the individual film was primarily intended to appeal to the American domestic market or simply have more allure to the British consumer with the additional possibility of generating dollar revenue, the American actors in the British films covered the full spectrum of Hollywood performers. These ranged from; highly bankable stars such as Gregory Peck (The Purple Plain (1954)) and James Stewart (No Highway In The Sky (1950)); to include slightly shopworn A-listers like Clark Gable (Never Let Me Go (1953) or Ginger Rogers (Twist of Fate (1954); mainstream American box-office draws like Alan Ladd (The Red Beret (1953) (USA title Paratrooper)) and Edward G. Robinson (My Daughter Joy (1950)); and B-movie stalwarts such as Richard Widmark (A Prize of Gold (1955)) or Forrest Tucker (Break In The Circle (1955)). The films absent of American stars but making clear reference to America were much fewer in number (less than ten films in total and no runaway films) and included, for example, the comedies; Orders Are Orders (1954), where Anglo-South African Sidney James has the role of a cigar-chomping Hollywood film director making a science-fiction film at a British Army Camp, much of the comedy being the contrast between American brashness and British propriety; and The Chiltern Hundreds (1949), where American actress Helen Backlin is listed low down the credits but the American persona of her character is a key driver of the whimsical plot narrative. 'The large number of Americanised films highlights how American influence on British film production went far beyond American film studios relocating capital to Britain for the production of runaway films. Reflecting growing American cultural and political hegemony over Western Europe, between 1948 and 1958 the content of British film outputs shifted to capture broader socio-cultural influences and promote American soft power whilst simultaneously both reworking British national identity to capture new geopolitical realties and satisfy the demands of British audiences whom had always been 
enthusiastic consumers of American films (Glancy 1999: passim; Goodwin 2006: xxiv;

Richards and Sheridan 1987: 58). Regarding the substance of the Americanised British films, just as the full range of American actors could be found across this body of work, Table 1 indicates that the American presence was equally widely spread over different genres of film.

Table 1. British long films, and the proportion of Americanised British long films, by genre 1948-58.

TOTAL OF BRITISH
FILMS BY GENRE
$1948-58$

\section{ADVENTURE}

COMEDY

CRIME

DRAMA

HISTORY

MUSICAL

ROMANCE

WAR

CHILDREN

SPORT

HORROR

FANTASY

REVUE

RELIGION

TOTAL

TOTAL OF
AMERICANISED
FILMS BY GENRE
$1948-58$

37

162

28

5

10

16

17

1

4

10

12

0

1

1171

7
45
162
28
5
10
6
17
1
4
10
2
0
1
48

AMERICANISED

FILMS AS \% OF

BRITISH TOTAL BY

GENRE 1948-58

$51 \%$
$16 \%$
$39 \%$
$23 \%$
$25 \%$
$26 \%$
$31 \%$
$29 \%$
$3 \%$
$36 \%$
$63 \%$
$29 \%$
$0 \%$
$17 \%$
$30 \%$

Source: Data compiled by author using Gifford (1973) and IMDB.com.

In addition to these figures highlighting the breadth of influence of American capital in British film outputs between 1948 and 1958, the thematic content of the Americanised films was indicative of changes in British society. Reflecting the relative postwar positions of Britain and the USA, whereby American global political, cultural, and economic ascendancy dovetailed with the rapidly diminishing status of Britain as a world power, the presence of American actors starring in British films conveyed how, to the British (and American) consumer, America represented glamour, daring, and courageous audacity. This being in contrast to the accepted British - or, more accurately, English - character traits of stoicism, reserve and temperate masculinity, all of which had been a staple of wartime and earlier films but had increasingly less traction with British cinema goers in the postwar years (Spicer 2003: 28-46). Thus it was American actors given the lead roles in adventure films portraying events from British history and mythology; Sea Devils (1953), set during the Napoleonic wars starring Rock Hudson and Yvonne DeCarlo; Star of India (1954), a swashbuckling seventeenth century adventure starring Cornel Wilde and Jean Wallace; and The Black Knight, an Arthurian themed potboiler starring Alan Ladd. Similarly, in adventure films given 
a contemporary setting in the, then, [British] Colony of Kenya, it is American actors in $1956 \mathrm{~s}$ Odongo who play the lead roles of the big-game hunter and veterinarian (Macdonald Carey and Rhonda Fleming respectively), whilst American Ken Duffield (Victor Mature) is the settler doing battle with the insurgent Mau Mau in Safari (1956). As well as British films appropriating the perceived glamour of American stars to lend the films allure to British and American audiences, a notable and frequent plot feature of the Americanised films mirrored the contemporary political relationship between Britain and the USA during the Cold War period. Tempering the obviously junior status of Britain in any 'special relationship' with the USA, British governments of the 1950s axiomatically clung to the belief that a synergy of British wisdom and American power acted as a progressive and benevolent force (Horne: 1998 160). Capturing such sentiments the films Highly Dangerous (1950) and South of Algiers (1951) both showed Anglo-American co-operation saving the day; in Highly Dangerous a British scientist Frances Gray (Margaret Lockwood) works with American journalist Bill Casey (Dane Clarke) to prevent a biological attack, whilst the combination of British knowledge and stoicism coupled with American derring-do and confidence is also a feature of South of Algiers where American author, Nicholas Chapman (Van Helfin), is instrumental in British archaeologist Dr Burnet (Eric Portman) finding a priceless artefact and saving it from unscrupulous treasure hunters. The communion of Britain and America in securing mutually beneficial goals - often through exploiting the stereotypical traits of British level-headedness and American bravado - is a prominent feature of Americanised British films across the genres. This includes the crime films; Dangerous Assignment (1950), where an Englishwoman helps an American reporter crack a stolen car racket; Circle of Danger (1951), showing an American assisted by an Englishwoman in discovering the truth about his brother's wartime death; and Escape Route (1953) (USA title I'll Get You), portraying an $\mathrm{FBI}$ agent in London working with $\mathrm{MI} 5$ to ensnare a gang of kidnappers working for the Soviets. Americanised British comedies and war films followed similar plot trajectories in emphasising both the differences in respective national personalities and the virtues of Anglo-American co-operation; Miss Pilgrim's Progress (1950) has a working class American exchange worker, who has swopped places with an upper class English girl, saving a village from unscrupulous developers; in both Meet The Duke (1949) and A Yank In Ermine (1955) respectively an American boxer and a G.I. inherit landed titles in England and solve problems by disregarding constricting class-bound formalities; whereas each of The Red Beret (1953) and No Time To Die (1958) (USA title Tank Force) show Americans enlisted in the British army providing invaluable assistance to Britain during the 1939-45 war.

Given the large number of Americanised films there were inevitably examples of films with Americans in Britain behaving in an antisocial or deviant manner; Night and The City (1950) has Harry Fabian (Richard Widmark) as an American criminal hustler operating on the fringes of the London underworld. Although this film also includes an 'honest American' role with Mary Bristol (Gene Tierney) as Harry's long-suffering love interest, and Harry redeems himself at the end of the film by ensuring a bounty placed on his head by a 
mobster boss he had offended goes to Mary. Films such as this are however atypical as the pervasive tone of Americanised films was of Americans and America being a progressive force for/in Britain. Thus The Million Pound Note (1954) (USA title Man With A Million) has Henry Adams (Gregory Peck), an American sailor stranded in Edwardian London, given the eponymous banknote by two wealthy brothers as a wager between themselves over how Henry will cope with this sudden influx of wealth. In this gentle albeit perceptive comedy Henry exposes the hypocrisy and materialism of those who judge him only by their perception of his wealth, and many lessons are learned as to the true worth of an individual. Even in films with a much less didactic thrust to them than the above example the dominant tone of Americanised British film portrays American identity and culture as meritocratic, egalitarian, and unburdened by the constricting conventions of orthodox English class hierarchies.

Americanisation of the North, 1948 to 1958.

Given portrayals of American culture and Americans in British film dovetail with the traditional representations of the North of England on film insofar as both were positioned as meritocratic, egalitarian, and possessing a disdain for class-bound social restrictions, the North of England might have been considered the natural location for the setting of Americanised British films. However the reality was markedly different to any such expectations.

The Americanisation of British film between 1948 and 1958 fell into two areas, each accounting for c.15 per cent of British outputs during the period. There were the runaway productions more focussed on the American domestic market and with plots and cinematography that traded heavily on the stereotypical tropes of authentic [Southern] English landscape and identity familiar to the American consumer. There were also the films orientated towards the British consumer that, given they relied upon either the juxtaposition of, or co-operation between, American culture and personality with those of England in order to drive the plot narratives, similarly employed the hegemonic norms of Southern English personality and geography. With both these areas of Americanised British film outputs relying upon non-Northern conceptualisations of England and Englishness the presence of the North on film during this period was marginal. Between 1948 and 1958 there were only seven Americanised British films set in the North, equating with only 2 per cent of the Americanised British films, and a mere 0.6 per cent of total British film outputs of the period.i This body of work consisted of two comedy films where a transatlantic focus of the plot - rather than transplanted American actors - is instrumental in driving the narrative; My Wife's Lodger (1952); and Ramsbottom Rides Again (1956), and five crime films starring or co-starring American actors; Forbidden (1949) (USA title Scarlet Heaven); Another Man's Poison (1951); The House Across the Lake (1954) (USA title Heat Wave); The Intimate Stranger (1956) (USA title Finger of Guilt); and The Long Haul (1957). 
Table 2. Northern-set British long films and Americanised Northern-set films, by genre 1948-58.

\begin{tabular}{l|cc}
\multicolumn{1}{c}{\begin{tabular}{c} 
TOTENRE \\
\multicolumn{1}{c}{$\begin{array}{c}\text { GENRE 1948-58 } \\
\text { GORTHERN FILMS BY }\end{array}$}
\end{tabular}} & $\begin{array}{c}\text { TOTAL OF AMERICANISED } \\
\text { NORTHERN-SET FILMS BY } \\
\text { GENRE 1948-58 }\end{array}$ \\
\hline COMEDY & 14 & 2 \\
CRIME & 12 & 5 \\
DRAMA & 6 & 0 \\
MUSICAL & 2 & 0 \\
CHILDREN & 1 & 0 \\
SPORT & 1 & 0 \\
HORROR & 1 & 0 \\
TOTAL & 37 & 7
\end{tabular}

Source: Data compiled by author using Gifford (1973) and IMDB.com.

This near invisibility of the North cemented its position as an 'other' to conceptualisations of England and Englishness. Yet, through this 'otherness' of the North and the content of Northern-set Americanised films which embraced American cinematic forms whilst simultaneously distancing themselves from the stylistic and thematic tone of wider Americanised British film outputs, the focus of the North's gaze was recalibrated away from England and towards America.

The two comedies, My Wife's Lodger and Ramsbottom Rides Again, both involve a Northern individual receiving a sizable inheritance from America. In Ramsbottom Rides Again the bequest is notionally in Canada. However the stereotypes employed; the 'wild west' saloon bar with swing doors; the hard drinking six-shooter wielding cowboys; the covered horsedrawn wagon; and the tee-pee inhabiting and peace-pipe smoking Native Americans, are all stock features of the American Western and, as such, firmly position the film within an American milieu. The film opens with diminutive and bespectacled Yorkshire publican Bill Ramsbottom (Arthur Askey) inheriting land from his Canadian Grandfather, 'Wild' Bill Ramsbottom. Problematically for Bill this inheritance comes with a requirement to serve as Deputy Sheriff of Lonesome, a lawless 'wild west' town being terrorised by Black Jake (Sidney James). Bill's patent unsuitability for the lawman duties provides the majority of the comedy material for the film. Inevitably, and inverting the routine narrative of Americanised British films portraying incoming Americans solving problems in Britain, Bill is ultimately triumphant in capturing Black Jake and bringing peace to Lonesome. In a similar vein demobbed soldier Willie Higginbotham (Dominic Roche) arrives back in his industrial Lancashire town after overseas service to find himself comically marginalised in his own home by the presence of a lodger, the draft-dodging spiv Roger (Leslie Dwyer), that his wife has taken-in during Willie's absence. The arrival of Tex (Alan Sedgwick), a brash bourbon drinking American, brings news to Willie of the inheritance of his Great Uncle's ranch in Texas. The film ends with Willie having exposed Roger as a criminal and with Willie and his family happily ensconced on the American homestead. Unlike the pattern of other 
Americanised British films, where the cultural and human drift is from America to Britain, these two films subvert this dynamic by having the direction of transatlantic travel and influence as being East to West, from England to America.

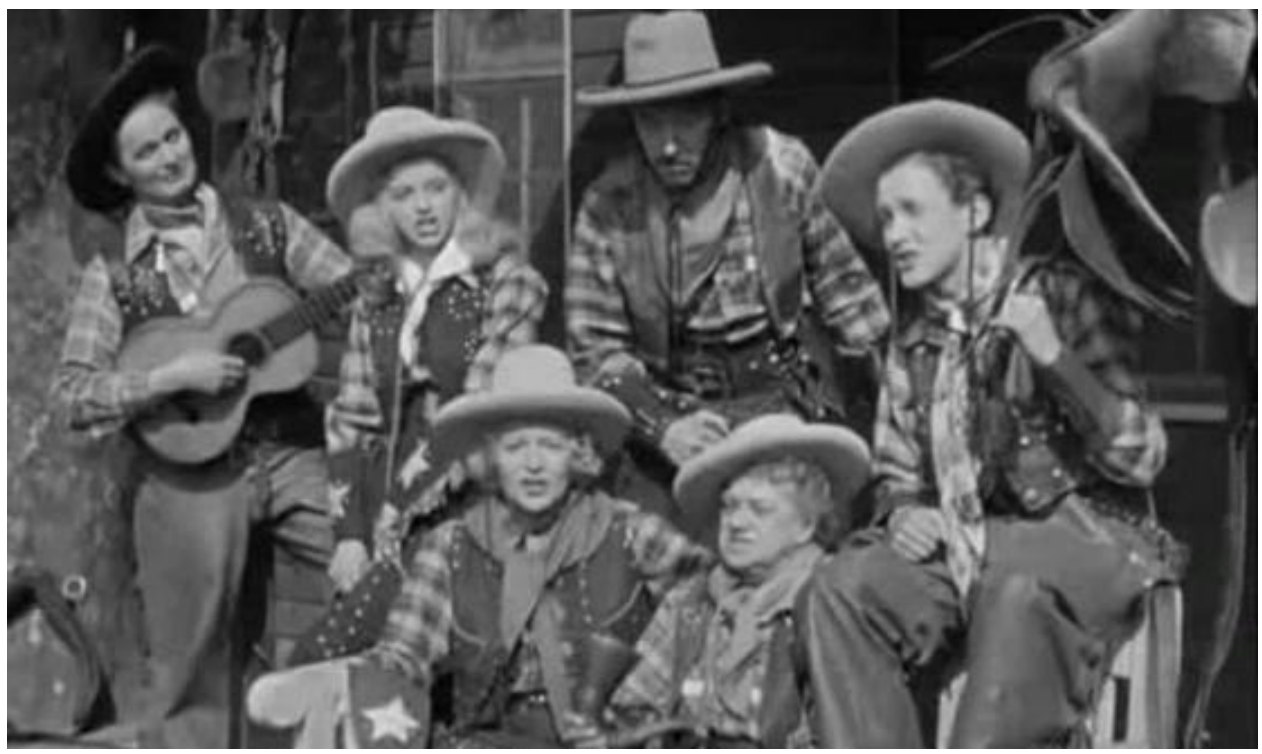

Lancashire's Higginbotham family 'home on the range' in Texas: My Wife's Lodger (1952).

These two comedies exist outside the routine dynamics of Americanised British film by both challenging the dominant narrative(s) of Americanised British film and by, implicitly at least, embracing the archetypal American cinematic form of the Western film. The remaining body of Northern-set Americanised British films followed a similar pattern in that these films both utilised characterisations and plots that were not representative of the larger body of Americanised British film and were also set within the thematic and stylistic parameters of a particularly American film genre, the film noir.ii

Table 3. Elements of Film Noir in each of the Americanised Northern-set crime films.

\begin{tabular}{|c|c|c|c|c|c|c|}
\hline FILM & $\begin{array}{l}\text { ANTI- } \\
\text { HERO }\end{array}$ & $\begin{array}{l}\text { FEMME- } \\
\text { FATALE }\end{array}$ & $\begin{array}{c}\text { SEXUAL } \\
\text { TENSION/TRANSGRESSION }\end{array}$ & $\begin{array}{l}\text { CRIMINAL } \\
\text { ACT(S) }\end{array}$ & $\begin{array}{c}\text { FLASHBACK/FIRST } \\
\text { PERSON } \\
\text { VOICEOVER }\end{array}$ & $\begin{array}{l}\text { LOW-KEY } \\
\text { LIGHTING }\end{array}$ \\
\hline FORBIDDEN & $x$ & $x$ & $x$ & $x$ & $x$ & $x$ \\
\hline $\begin{array}{l}\text { ANOTHER } \\
\text { MAN'S } \\
\text { POISON }\end{array}$ & $x$ & $x$ & $x$ & $x$ & & $x$ \\
\hline $\begin{array}{l}\text { HOUSE } \\
\text { ACROSS } \\
\text { THE LAKE }\end{array}$ & $x$ & $x$ & $x$ & $x$ & $x$ & $x$ \\
\hline $\begin{array}{l}\text { THE LONG } \\
\text { HAUL }\end{array}$ & $x$ & $x$ & $x$ & $x$ & & $x$ \\
\hline $\begin{array}{l}\text { INTIMATE } \\
\text { STRANGER }\end{array}$ & $x$ & $x$ & $\mathrm{x}$ & $x$ & $x$ & $x$ \\
\hline
\end{tabular}

Source: Data compiled by author.

In addition to each of these films employing the characteristics of the film noir, thereby distancing the North from established English or Northern identities whilst simultaneously 
positioning it within the sphere of American cinematic influence, the most potent manner in which these films departed from the larger body of Americanised British film was through the portrayal(s) of American character(s) in these films. In contrast to the imagery and personality of Americans in the larger body of Americanised British film as being a benevolent and edifying influence, the Americans located in the North were all participants in criminal or other antisocial activity. These acts included; murder/manslaughter, Forbidden, Another Man's Poison, The House Across The Lake, and The Long Haul; adultery, Forbidden, Another Man's Poison, The House Across The Lake, The Long Haul, and The Intimate Stranger; fraud and theft, Another Man's Poison, The Long Haul, and The Intimate Stranger; and blackmail; Another Man's Poison, The House Across The Lake, and The Intimate Stranger.

Moreover, satisfying a number of the key tropes of the film noir and also departing from the rare displays of criminality of Americans in non-Northern outputs where the Americans are established as criminal from the outset (i.e. Night And The City, where the American is a small-scale hustler, or Kill Her Gently (1957) with an American escaped convict), in the Northern-set Americanised films the American characters start out as well-intentioned and honest but, through the influences they are exposed to in their Northern environment and having fundamentally flawed characters (unlike the 'ideal type' personalities present in nonNorthern Americanised British film), they ultimately find themselves corrupted by external influences and/or their own human weaknesses.

Thus Forbidden begins with Canadian ex-serviceman and chemist Jim Harding (American actor Douglas Montgomery) optimistically opening a business selling quack hair restoration and libido potions of his own concoction from a stall on Blackpool Promenade. Jim's demise is mapped out through his falling in love with Jane, an ice-cream vendor on a neighbouring stall, and seeking escape from his unhappy marriage (in order to be with Jane) by poisoning his wife. Similar patterns of character downfall where the American lead characters begin as honest and, after succumbing to the baser human imperatives of lust and greed, find themselves losing everything occur in The Long Haul, The House Across The Lake, and Another Man's Poison. In The Long Haul it is former G.I., Harry Miller (Victor Mature), working as a long distance lorry driver and living in Liverpool with his British wife and son who, after allowing himself to become romantically involved with a gangster's femme fatale girlfriend, is embroiled in murder, adultery, haulage theft, and insurance fraud. The House Across The Lake opens with a hardboiled voiceover straight out of an American dime detective novel from the main protagonist, American writer Mark Kendrick (Alex Nicol),

“...six weeks ago I was just a hack novelist trying to beat some life into a dying book. I'd taken that bungalow on Lake Windermere to get away from fast blondes and sloe gin only to discover my neighbours across the lake had a habit of living it up every other night..." 
It emerges that the house across the lake is owned by Beverley Forrest (Sidney James), a tycoon with a heart condition and a much younger trophy wife, Carol Forrest (American actress Hillary Brooke). The inexorable path to Mark's demise is via his seduction by Carol who involves him in her husband's murder. American bank clerk George Bates (Gary Merrill) is the corrupted innocent in Another Man's Poison. This film opens with George arriving at a country house on the edge of the Yorkshire Moors seeking Mr Preston, the man who persuaded him to take part in a bank robbery and then fled, both abandoning and implicating George, when the heist went wrong. By the end of the film George is a blackmailer and an accessory to murder. In The Intimate Stranger the corrupting influences of the North are much less clear cut insofar as Reggie Wilson (American actor Richard Baseheart) is a former Hollywood film cutter who moved to Britain after scandals of his philandering past caught up with him in America. With a only little over a quarter of the film's on-screen time being in Newcastle, the remainder of the film set in a London film studio where Reggie is a successful producer having married the boss' daughter, it is only when in the North that Reggie's character lapses to his recidivist ways with a fumbled attempt at seduction of an American woman, who is not his wife, that is blackmailing him. As such, in this and the other Northern-set Americanised films, the location of the North as a place where moral ambivalence gives way to temptation is again presented as being distinct from and different to the routine plot and character types of the larger body of Americanised British film where the American characters and culture ultimately uplift the environment within which they are located.

Visually, in addition to low-key lighting typical of the genre found in all of the Americanised Northern noirs (most prominently in The Intimate Stranger where the majority of the film's on-screen time in the North was at night), the mise-en-scene of this body of work - with composition, backdrops, and even occasional costumes that were evocative of American environments - positioned the North outside the aesthetics of English national identity. The North was instead placed within cultural and physical landscapes that were American in tone and style. Whether as an aerial shot of Liverpool docks reminiscent of the New York or Chicago waterfronts found in The Long Haul or, whilst the terrain has sheep and limestone boulders instead of tumbleweed and cacti, a sweeping vista with two characters riding out on horseback across the Yorkshire moors in One Man's Poison invoking associations with the American Western, the Northern-set Americanised films distanced the North from British film outputs through their employment of American visual motifs. With glitzy and noisy fairground backgrounds and the bustling Blackpool promenade redolent of Coney Island and Atlantic City, the sharp zoot clothing of the street hustlers who loiter around the boardwalk, and Jim's apartment in a building with improbably stylish deco interiors, Forbidden is loaded with imagery that locates the stylistic tone of the film within American cinematic norms. Similarly The House Across The Lake presented a North of open Lake District landscapes (admittedly through the use of stock footage) akin to the panoramas of the American Western. This film also presented a sophisticated, if decadent, North with swish cocktail 
parties - with champagne and caviar unusual in a postwar Britain still undergoing food rationing for the guests to feast upon - held at a grand house draped in lights and, making an explicit cultural reference to America, "...looking something like a world premiere at [Hollywood's] Grauman's Chinese Theatre".

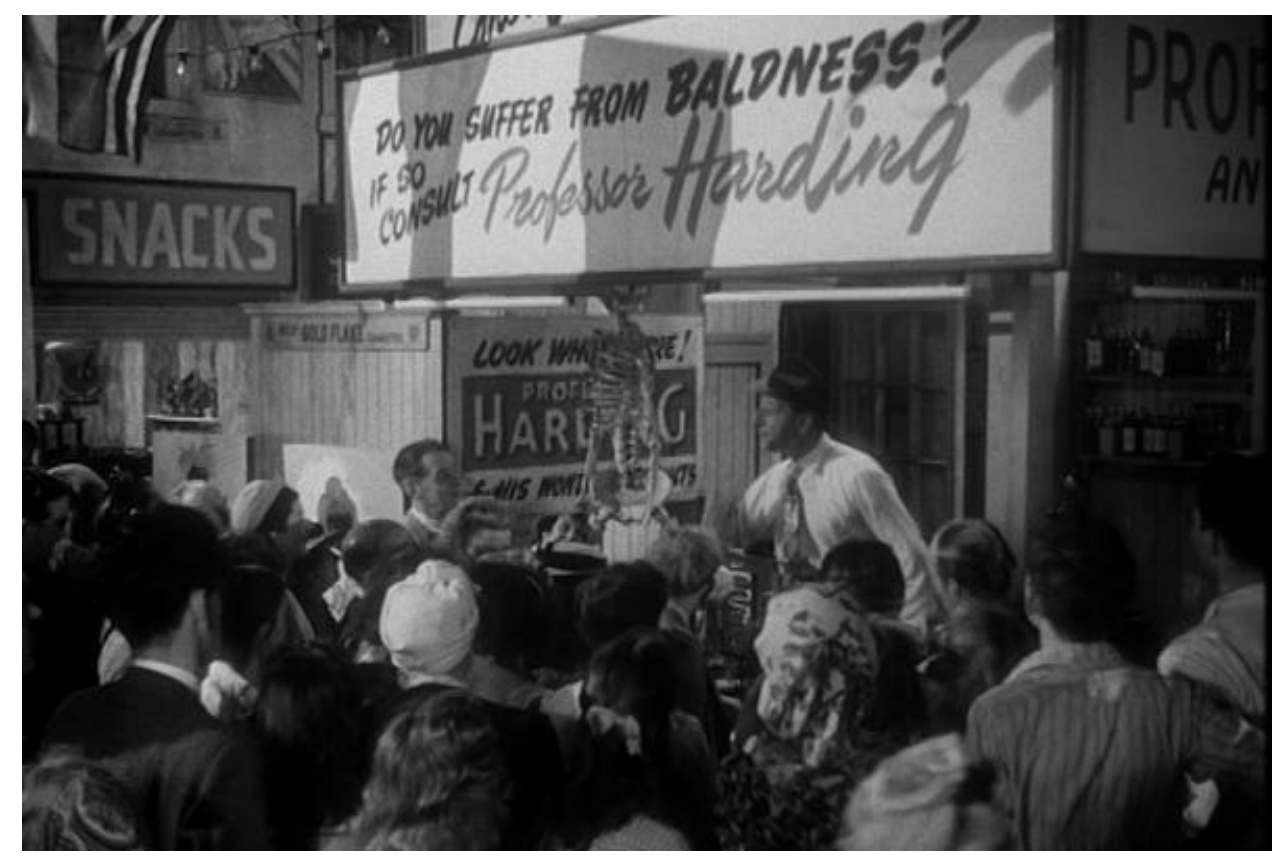

Panaceas on Blackpool promenade: Forbidden (1949).

Through a combination of the marginal numerical presence in Americanised British film together with Americanised British films set in the North having characters, plots, and visual representations that diverged pointedly from the norms of the wider body of Americanised British film set outside the North, the North was located firmly outside conceptualisations of England and Englishness in Americanised British film between 1948 and 1958. Unlike, however, other epochs in British film output when the representations of the North on film retreated into the established mores of it being an environment inhabited by a stoical and/or comedic working class, the North in Americanised British film abandoned such traditional precepts to instead be presented as an authentically American environment. Turning away from Britain and towards America, through the stylistic and thematic content of the Northern-set films exploiting the archetypal American cinematic forms of the film noir and, to a lesser extent, the Western, the identity and outlook of the North was positioned outside the parameters of Britain or England and firmly existed within an American domain. Moreover the American characters in Northern-set Americanised British film deviated from British cultural types and stock characters to instead adopt American forms such as the femme fatale and, more significantly, the antihero. Unlike American characters present in the large majority of Americanised British film who possessed the personality and cultural traits of honesty, morality, courage, and idealism, the American, and other, lead characters in Northern-set Americanised British film rejected these conventional attributes and were burdened with character flaws that highlighted the human frailties of greed, avarice, lust, 
and self-interest. In an era where Americanised British film served as a means of propagating American hegemony over Britain the presence of antihero characters in the North not only served to locate the North outside the canon of national identity but laid the groundwork for the British new wave that emerged in the late 1950s. In spite of Robert Murphy's assertion that "American involvement in the British 'new wave' was minimal" (Murphy 1992: 257), this is true only of the British new wave film as an industrial economic process. As a cultural process the iconoclastic and hedonistic characters evident in the British new wave had direct antecedents in Americanised British films set in the North. The compromised morality and self-motivated behaviour found in Forbidden, Another Man's Poison, The House Across The Lake, The Intimate Stranger, and The Long Haul were all, albeit less criminally, replicated in British new wave films of 1959-63, and the phenomenon of the British new wave that is considered an example of British and, even, northern cinematic exceptionalism emerged directly from Americanised Northern-set British films of the 1948 to 1958 period.

Works cited.

Anderson, Lindsay (1957) 'Get Out And Push', in Tom Maschler, (ed.), Declaration (London: MacGibbon and Kee), pp.154-178.

Board of Trade Journal (1948). Volume 154, 30 ${ }^{\text {th }}$ April 1948.

Burnup, Peter (1948). 'Outlook is Bleak for British Exhibitors', Motion Picture Herald, Volume 170, no.1, January $3^{\text {rd }} 1948$, p. 19.

Dellheim, C. (1986) 'Imagining England: Victorian Views Of The North', Northern History, Vol. XXII pp.216-230.

Gifford, Denis (1973) The British Film Catalogue 1895-1970 (New York: McGraw Hill Book Company).

Glancy, Mark (1999). When Hollywood Loved Britain: The Hollywood 'British' Film 1939-45 (Manchester: Manchester University Press).

Goodwin, Andrew (2006) 'Introduction', in Richard Hoggart, The Uses of Literacy (New Brunswick: Transcation Publishers).

Harper, Sue and Porter, Vincent (2003). British Cinema of the 1950s: the Decline of Deference (Oxford: Oxford University Press, 2007 edition).

Horne, Alistair (1988). Macmillan, 1894-1956: Volume I of the Official Biography (London: Macmillan). 
House of Commons (Debate) (1948). Film Industry, 30 ${ }^{\text {th }}$ April 1948, Volume 450, Columns 862-874.

House of Commons (Debate) (1948). Anglo-American Films Agreement, $17^{\text {th }}$ June 1948 , Volume 452, Columns 737-778.

Jewell, Helen (1994). The North-South Divide: The Origins of Northern Consciousness in England (Manchester: Manchester University Press).

Marwick, Arthur (1998). The Sixties: Cultural Revolution in Britain, France, Italy, and the United States, c. 1958-.c. 1974 (London: Bloomsbury, 2011 edition).

Murphy, Robert (1992). Sixties British Cinema (London: BFI Publishing, 1997 edition).

Perilli, Patricia (1983). 'Statistical Survey of the British Film Industry', in James Curran and Vincent Porter (eds.), British Cinema History (London: Weidenfeld and Nicolson), pp. 372382.

Pocock, D.C.D. (1978). The Novelist and The North (Durham: Publications of the Department of Geography Durham University).

Richards, Jeffrey (1997). Films and British national identity: From Dickens to Dad's Army (Manchester: Manchester University Press).

Richards, Jeffrey and Sheridan, Dorothy (eds.) (1987). Mass Observation at the Movies (London: Routledge).

Romer, Stephen (1993). The Decline of the British Film Industry: an analysis of market structure, the film and product competition (Brunel University Department of Economics: Unpublished PhD Thesis).

Russel, Dave (2004). Looking North: Northern England and the National Imagination (Manchester: Manchester University Press).

Scott, Peter (2007). Triumph of the South: A Regional Economic History of Early Twentieth Century Britain (Aldershot: Ashgate).

Shields, Rob (1991). Places On The Margin: Alternative geographies of modernity (London: Routledge).

Spicer, Andrew (2003). Typical Men: The Representations of Masculinity in Popular British Cinema (London: I.B. Taurus).

Street, Sarah (1997). British National Cinema (London: Routledge). 
Stubbs, Jonathan (2009) 'The Eady Levy: A Runaway Bribe? Hollywood Production and British Subsidy in the Early 1960s', Journal of British Cinema and Television, Volume 6, Issue 1, May 2009, pp. 1-20.

Toumlin, Vanessa (2006). Electric Edwardians: The Story of the Mitchell \& Kenyon Collection (London: British Film Institute).

Wiener, Martin J. (1981). English Culture and the Decline of the Industrial Spirit (Harmondsworth: Penguin, 1985 edition).

\footnotetext{
i An Americanised British film has been determined as a film where one or more American actors are listed in the top four acting credits of a film, either in Gifford (1973) or on http://www.imdb.com. It also includes films; where an American actor played a Canadian, for example Douglass Montgomery in Forbidden (1949); where a non-American 'Hollywood' actor, for example Australian born Errol Flynn, played an American character; and where a non-American actor played an American character, for example Canadian Robert Beatty often played American parts. The figure does not include films where an American born actor, who made his/her career in Britain playing British characters, is listed in the top four acting credits (for example films starring Peter Williams or James Maxwell), or films that are clearly aping American forms but include no American actors or explicit references to America in driving the plot narrative (for example Rock You Sinners (1957) or The Tommy Steel Story (1957) were both clearly inspired by American Rock and Roll music).

ii This figure is however reflective of the absence of the North in British film outputs of the time whereby, of the 1171 'long' films made during this period, only 37 were set/partly set in the North (3 per cent). Data extrapolated by author from Gifford (1973).

iii Given its French etymology films noirs would, linguistically, be the correct phraseology to employ in describing the plural of film noir. The author has, however and with apologies to those offended by the taking of such license, anglicised the term and the plural of 'film noir' is referred to in the text as 'film noirs'.
} 